\title{
Model package of Behavioral Change Communication regarding childhood pneumonia and its risk factors: a pre-post assessment
}

Prakash Prabhakarrao Doke ${ }^{1,}$ Gothankar Jayashree Sachin ${ }^{2}$, Dhumale Girish Bhimrao ${ }^{3}$, Pore Prasad Dnyandeo ${ }^{4}$, Lalwani Sanjay Kewalchand ${ }^{5}$, Quraishi Sanjaykumar Raguel ${ }^{6}$, Murarkar Sujata Kapil ${ }^{7}$, Patil Reshma Sudhir ${ }^{8}$, Waghachavare Vivek Baliram ${ }^{9}$, Dhobale Randhir Vishnupant ${ }^{10}$, Palkar Sonali Hemant ${ }^{11}$

${ }^{1}$ Professor Department of Community Medicine, Bharati Vidyapeeth Deemed University Medical College, Pune, Maharashtra, 411043; . ${ }^{2}$ Professor and HOD Department of Community Medicine, Bharati Vidyapeeth Deemed University Medical College, Pune, Maharashtra, 411043; ${ }^{3}$ Professor and HOD Department of Community Medicine, Bharati Vidyapeeth Deemed University Medical College, Sangli, Maharashtra, 416410; ${ }^{4}$ Professor Department of Community Medicine, Bharati Vidyapeeth Deemed University Medical College, Pune, Maharashtra, 411043; ${ }^{5}$ Professor Department of Pediatrics, Bharati Vidyapeeth Deemed University Medical College, Pune, Maharashtra, 411043; ${ }^{6}$ Professor Department of Community Medicine, Bharati Vidyapeeth Deemed University Medical College, Sangli, Maharashtra, 416410; ${ }^{7}$ Associate Professor Department of Community Medicine, Bharati Vidyapeeth Deemed University Medical College, Pune, Maharashtra, 411043; ${ }^{8}$ Associate Professor Department of Community Medicine, Symbiosis Medical College for women, Pune, Maharashtra, 411004; ${ }^{9}$ Associate Professor Department of Community Medicine, Bharati Vidyapeeth Deemed University Medical College, Sangli, Maharashtra, 416410; ${ }^{10}$ Associate Professor Department of Community Medicine, Bharati Vidyapeeth Deemed University Medical College, Sangli, Maharashtra, 416410; ${ }^{11}$ Associate Professor Department of Community Medicine, Bharati Vidyapeeth Deemed University Medical College, Pune, Maharashtra, 411043

\begin{tabular}{|c|c|c|c|c|c|c|c|c|}
\hline Abstract & Introduction & Methodology & Results & Conclusion & $\underline{\text { References }}$ & Citation & & ples / Figures \\
\hline \multicolumn{9}{|c|}{ Corresponding Author } \\
\hline \multicolumn{8}{|c|}{$\begin{array}{l}\text { Gothankar Jayashree Sachin, Professor and HOD, Department of Community Medicine, Bharati Vidyapeeth } \\
\text { Deemed University Medical College, Pune, Maharashtra, } 411043 . \\
\text { E Mail ID: jayashreesg@rediffmail.com }\end{array}$} & 回部回 \\
\hline
\end{tabular}

\section{Citation}

Doke PP, Gothankar JS, Dhumale GB, Pore PD, Lalwani SK, Quraishi SR, Murarkar SK, Patil RS, Waghachavare VB, Dhobale RV, Palkar SH. Model package of Behavioral Change Communication regarding childhood pneumonia and its risk factors: a pre-post assessment. Indian J Comm Health. 2020;32(1):67-75.

Source of Funding: The Bill and Melinda Gates Foundation (OPP 1084307) through The INCLEN Trust International, NewDelhi, India under Grant (Project ID; INC2015GNT006) supported the study.

Conflict of Interest: None declared

\section{Article Cycle}

Received: 17/12/2019; Revision: 18/01/2020; Accepted: 25/02/2020; Published: 31/03/2020 This work is licensed under a Creative Commons Attribution 4.0 International License.

\section{Abstract}

Background: Many risk factors contribute to high morbidity and mortality due to childhood pneumonia. Mostly the risk factors are modifiable and related to behavior. Imparting knowledge to mothers about risk factors, early recognition of danger signs and importance of timely seeking health care is an accepted strategy for control. Aims \& Objectives: To assess improvement in knowledge and perceptions about childhood pneumonia, risk factors and hand washing skills among mothers after sequential use of different media. Materials \& Methods: This community based, pre and post assessment study was conducted in eight randomly clusters from two districts. Specially field supervisors assessed mothers for their 'knowledge', 'perceptions' and 'skills' about nutrition including breast feeding and malnutrition, indoor pollution, pneumonia and hand washing. Knowledge was assessed pertaining to all four aspects, perception was assessed for first three and skills were assessed only for hand washing. Three rounds of BCC using pictorial booklet, audio-visual film and flash cards consequently were completed, spread over about one year. Marks pertaining knowledge, perceptions about risk factors of childhood pneumonia and hand washing skills etc. were separately measured. Results: A total of 1,321 mothers participated. The mean pre-test marks were 22.31 out of 38 marks which significantly improved and retained to 35.24 after undergoing three BCC rounds. Highly significant improvements, 2.27 times in hand washing skills to 1.15 times for knowledge about indoor air pollution was observed. Conclusions: Consecutive use of different media at appropriate interval spread over a long period certainly yields desired results at diverse places. 


\section{Keywords}

Knowledge; Perceptions; Hand washing skills; Maharashtra

\section{Introduction}

Among under five children pneumonia is a major global health problem, ranking first amid causes of death, accounting for $15-20 \%$ deaths. $(1,2,3)$ In India $3.1 \%$ to $27.6 \%$ deaths are attributed to pneumonia. $(4,5,6)$ Lowest global estimate for episodes of pneumonia and for severe pneumonia were 120 million and 14 million respectively. (7) The global estimated number of deaths due to pneumonia was 0.92 to 2 million. $(2,3,7)$ There is certainly declining trend in total as well in proportional deaths. (8) In India about 43-44 million childhood pneumonia cases occur per year, but it may be overestimate. $(5,9,10)$ About 3.6 million episodes of severe pneumonia and 0.35 to 0.41 million deaths occur yearly in India. $(3,11)$ The global estimated incidence of pneumonia in 1990-2010 was 0.26 episodes per child year; in South East Asia region, it was about 0.36 and in India the range was 0.03 to 0.52 with state wise disparities. $(9,12,13)$ The proportion of children having symptoms of ARI preceding two weeks of survey has ranged from 2.7 to $19.0 \%$. $(13,14)$

Reduction of under-five mortality as envisaged in Sustainable Development Goals cannot be accomplished unless community acquired pneumonia is substantially reduced. Various risk factors for morbidity and mortality are documented. The risk factors affecting incidence are classified into definite, likely and possible. Definite risk factors include five or six factors which are most are modifiable. $(9,15)$ The risk factors for mortality include lack of awareness among mothers about symptoms and dangers signs. The primary strategy for controlling childhood pneumonia should be reducing risk factors both for morbidity and mortality. Mother is primary caretaker for children, hence she must be knowledgeable. $(16,17)$ Many interventions recommended by WHO and UNICEF are related to behavior change among mothers. $(2,18)$ Large studies assessing knowledge of risk factors and then effect of frequent use of various media are rare. The imparted knowledge and changes perceptions must be long lasting.

\section{Aims \& Objectives}

The objectives of present study were; to assess knowledge and perceptions about childhood pneumonia, risk factors and hand washing skills among mothers and to measure the effectiveness of a package, containing different media of Behavioral Change Communication (BCC).

\section{Material \& Methods}

This community-based intervention study was conducted in urban and rural field practice areas of two medical colleges, located in Pune and Sangli districts, in Maharashtra State, India. There are 19 slums and 26 villages in field practice areas, hereafter termed as clusters. Total eight clusters, four each in urban and rural areas were randomly selected for BCC as depicted in (Figure 1). The study was conducted in 2015-17. Mothers of under five years children were the participants in the study.

The study was conducted by faculties from Community Medicine and Pediatrics Department. For each site one faculty was designated as Site Investigator (SI). Trained eight Field Supervisors (FS) collected the data. They were 12 standard pass and Marathi (local language) speaking women. We sought cooperation from Accredited Social Health Activists (ASHA), Angan Wadi Workers (AWW) through concerned government officers.

The study was approved by the Institutional Ethics Committees. The participants were recruited after obtaining written informed consent.

\section{Instruments}

1. A Marathi pictorial booklet having five aspects; child nutrition (breast feeding, weaning and malnutrition), immunization, in-door air pollution including smoking and coughing etiquettes, signs and symptoms of pneumonia and hand washing was prepared after consultative process. The steps of hand washing were based on UNICEF's recommendations; (19) and other part on available documents. $(20,21)$ It was validated and pretested.

2. An audio-visual Marathi film of 28 minutes duration, based on booklet was prepared. It consisted total five clips of 4-8 minutes duration each, on the aspects mentioned above.

3. Flash cards based on booklet were prepared.

4. Questionnaire for assessment of effectiveness of the BCC activity was also validated and pretested. It had three domains (knowledge, perceptions and skills) of four aspects (nutrition, indoor air pollution, signs/symptoms of pneumonia and hand washing) as given in (Table 1). Total nine components were covered as given in (Table 2). Maximum possible marks were 38. There were 13 questions having closed answers and fourteenth was observational check list for steps of hand washing. Answers were either multiple choices, tick marks or true and false ascertainment. Some questions were having only one and some having more answers, accordingly marks were distributed. Correct answer was given one mark and incorrect zero. Same instrument was used in pre and post-test assessment.

\section{Intervention}

Initially FS through house to house visits enlisted all mothers having under-five children. They were invited by ASHA/AWW to attend rounds of BCC sessions in groups of 8-10. Activities were simultaneously conducted by four teams, each having a pair of FS. Pre-test questionnaire was distributed and instructions were given about filling it. Each mother was requested to demonstrate her usual 
hand washing practice. While observing the act FS filled the last part of the questionnaire about hand washing skills. Then they were asked to sit in the form of a circle. One booklet was given to each mother. The contents of the booklet were explained. Then step-wise demonstration of hand washing was given by FS. The booklets were kept with mothers and they were requested to read frequently.

After two months, second round of BCC activity was conducted. The audio-visual film was shown to groups of 10-15 mothers. After that the FS summarized important aspects in the film. The mothers were gifted soap and soap case for inculcating acquired skills. Both the sessions lasted for about three to four hours. The SIs conducted quality checks through supervising $10 \%$ of total sessions. After three months of completion of second round, FS contacted each woman at her house and interacted with her using flash cards. The purpose of this visit was to assess the knowledge and observe the hand washing practices and reinforce as required. First two post-tests were conducted after each session. The final post-test for each mother was carried out in homes, three months after third round. All tests included assessment of hand washing skills.

\section{Data analysis}

Data were analyzed using Statistical Package for the Social Sciences (SPSS) software version 25. The paired and unpaired ' $\mathrm{t}$ ' test and ' $\mathrm{F}$ ' test were applied. A value of $p<0.05$ was considered as significant.

\section{Results}

In the study 1,549 mothers were enrolled. Only 228 mothers did not take all four tests; hence excluded from analysis. The question wise marks of pre-test and third post-test is given in (Table 1). The mean total marks in pretest were 22.31 (S.D. =3.96), and in post-test were 35.24 (S.D. =2.76). After three rounds of BCC almost all the mothers have shown improvement in their knowledge, perception as well skills. Highest improvement, 2.27 times was seen for hand washing skills and the lowest improvement, 1.15 times was observed in knowledge about in-door air pollution. However in all three domains and four aspects, improvement was highly significant. Rest of the observations in subsequent tables are presented, aspect and domain wise and not question wise.

Marks obtained by mothers from urban and rural are given in (Table 2). In pre-test the total marks were similar. In all components excepting perception about pneumonia, improvement was more in area (urban/rural) where initial marks was lesser.

Almost $60 \%$ mothers were below 25 years of age. Age group wise knowledge and perceptions of mothers including hand washing skills and improvements occurred after three rounds of BCC is given in (Table 3 ).
The overall marks were similar in both the age groups; excepting the correct perception about indoor air pollution and its effects which were better among older mothers. It was observed that overall improvement in knowledge, perception and skills was similar in both the age groups. The hand washing skills improvement was better among younger mothers.

The educational level of mothers and their knowledge and perception before BCC activities is given in (Table 4).

The knowledge, perceptions and skills, excepting perceptions about indoor pollution and pneumonia, were significantly related with level of education.

After BCC activities differential achievements in the knowledge, perception and skills with respect to educational level are given in (Table 5). Improvements in six components were proportional to education. It was observed that gain in marks was more among less educated mothers compared to highly educated.

\section{Discussion}

Although serious concern is always expressed about childhood pneumonia, attention towards educating mothers is comparatively neglected. Although the etiology of child pneumonia is complex and multifactorial, the role of mothers' knowledge, perceptions and practices cannot be undermined.

\section{Design}

Pneumonia control needs protect, prevent and treat strategy. Knowledge of risk factors and protection from them, recognition of danger signs of pneumonia by mothers and consequent health care seeking behavior are crucial determinants. Three delays have been described for mortality due to pneumonia; delay in recognition of symptoms, decision to seek care and delay in seeking qualified medical care. (17) Many mothers may seek services from hospital; (22) but only $50 \%$ receive appropriate treatment. (10) A large number of risk factors are behavior related. Hence WHO and UNICEF have strongly recommended education of mothers for recognition of danger signs and symptoms of pneumonia for improving care seeking behavior. (10) One time interaction with mothers certainly is not adequate for optimum knowledge gain as well its retention. Many studies have assessed knowledge, attitudes and practices of mothers. (23-29) Qualitative methods like focused group discussions, in-depth interviews etc. are also frequently utilized. $(17,22,30)$ Majority studies are hospital based. $(1,24,27,30,31,32,33,34)$ In the present study 1,321 mothers interacted regularly for a span of one year; this sample size is larger than several reported studies. $(1,23-26,30,31,32,33,34,35)$ Community based studies are diverse by study locations, numbers of participating mothers etc. Both urban and rural areas were involved, (25-26) only rural areas have been studied, (36) More than eight clusters also have been studied; 
$(16,23,26,29)$ but some of them are exclusively hand washing studies.

In present study, in contrast to most of the studies, the scope of assessment was larger, spread over knowledge, perceptions and skills of four aspects. The assessment instrument was overarching risk factors, recognition of danger signals and health care seeking behavior etc. Table 1 clearly shows that emphasis was given on hand washing and skills were only assessed in this aspect. The preparation of instruments was fairly methodical though not alike a reported study. (37) Over and above the large sample size and many clusters; the interactions with mother continued for about one year using different media had its own merit in our study.

\section{Knowledge and perceptions about risk factors}

Out of five definite risk factors three modifiable factors (breast feeding, indoor air pollution and nutrition) were selected. (15) Crowding is not easily modifiable and low birth weight is more relevant among women in general. Present study participants were women already having children. Hence these two factors were not included. On the other hand mothers' knowledge/perception about pneumonia and hand washing were included considering the enormous evidence available about their role in controlling pneumonia. Poverty, poor immunization status, indoor air pollution, overcrowding, malnutrition, particularly weight for height, poor nutritional practices, mothers' knowledge, day care center attendance, low birth weight and grand multi-parity have been repeatedly endorsed risk factors. $(12,35)$ In a study most commonly perceived risk factors by mothers were 'being under the age of five years' and 'an underlying lung disease' and least commonly perceived factors were 'lack of exclusive breastfeeding' and 'attending a child day care'. (32) In another study women felt that the risk of developing pneumonia increases when children are exposed to unsafe fuel use for cooking and parental smoking. $(38,39)$ In present study, $78.80 \%$ mothers had correct knowledge/perception about indoor air pollution and $63.00 \%$ mothers about malnutrition. The assessment of risk factor from medical fraternity is invariably different from mothers' perspective. For controlling pneumonia improvement in nutrition, control of indoor air pollution, exclusive breast feeding, identification and management of pneumonia have been recommended strategies. $(3,18)$ Hand washing

Advocacy, education, behaviour change are three sequential steps in promoting hand washing. (40) Promotion of hand washing is considered as one of the potent preventive strategies. (32) Majority of the studies had demonstrated that hand washing can reduce ARI by around 23 to $50 \%,(4142,43,44)$ excepting one. (45) Many mothers in one study opined that hand washing could prevent ARI. (16) We assessed knowledge about moments of hand washing as well as skills. Six methods of assessment of hand washing measures are advocated.
(46) Hand washing compliance may be measured by observation, self-reporting and indirectly by calculation of usage of soap. (26) In present study $68 \%$ mothers correctly identified moments necessitating hand washing. Although the women in one study knew the importance of hand washing using soap, but majority felt only water was enough and one third from rural area felt that even ash may be used. $(16,26)$ Studies in other areas had shown that after defecation or changing nappies of babies, all washed hands with soap in urban area and $85 \%$ in rural areas, $(16,26)$ whereas only water was used for hand washing, before preparing or feeding food by $55 \%$ to almost all mothers. $(16,26)$ The importance of hand washing before meal was perceived better than after defecation, and least importance was given to hand washing before feeding a child. (16) After defecation 98\%, before eating $38-79 \%$, after changing babies' defecated napkins $38-44 \%$, before preparing food $30-35 \%$ mothers washed hands. (44) Although most mothers used soap after defecation but ash was also used. (47) After two inter personal communications, soap use increased to $65-98 \%$. (47) Worldwide only $0-34 \%$ people wash hands after crucial moments like using toilet and prior to food handling. (41) Mothers give differential importance to different moments of hand washing. Moments of hand washing are frequently studied but steps are rarely. In current study performing all steps increased from 30\% to 95\%. Comparable improvement in performing corrects steps from zero to about $45 \%$ was observed. (47) In a study, $77 \%$ of the respondents followed only two steps for hand washing. (26)

\section{Breast feeding}

Among mothers attending pediatrics department correct knowledge about breast feeding ranged from 35 to $80 \%$, similar to our pre-test marks $) 56.67 \%)$. (48,49,50,51) Reports of latest national level surveys indicate that in Maharashtra 57.5 to $71.2 \%$ women initiated breast feeding within an hour and $37.6 \%$ to $56.6 \%$ mothers exclusively breast fed their children. $(14,52)$ The statistics are lower than the knowledge level observed in the study. Implementing breast feeding initiative activities need still enhanced implementation.

\section{BCC Activities}

Our interactive sessions were longer than other studies. $(1,34)$ In some studies printed media with or without lecture were used to impart knowledge. $(1,31,34,53)$ Audio-visuals were also used in focused group discussions. $(22,37)$ Interventional studies with comparison group usually demonstrate significant positive effects. $(1,34,53)$ Inter personal communications twice in one month had shown improvement. (47) A combination of methods including house to house visits like present study for improving hand washing techniques had shown highly significant results. (43) The combination of activities and media used in this study will be certainly useful in diverse locations. 


\section{Associations between different variables}

Although mothers from urban and rural areas had similar overall marks in present study; urban mothers may have better knowledge. $(23,36)$ But in one study in post-test rural mothers obtained more marks than urban. (1) In present study the urban-rural gaps was minimized after BCC. Unlike our study, many studies observed relation between knowledge and age group. Age and knowledge/ perceptions relationship is varied. $(28,54)$ Higher education is almost universally associated with better knowledge /perception, $(28,54,55)$ hence promoted. (56) We observed that although knowledge was proportional to education, perception was not.

\section{Knowledge and perception about pneumonia}

Mother may have knowledge about pneumonia after her child is admitted. (33) Similar to present study, combined knowledge and perception scenario was observed in other studies. (27-28) Knowledge about signs and symptoms among mothers varies from poor to adequate. $(1,17,24,30-31,36,54) \quad$ Despite affirming knowing pneumonia, only $24.4 \%$ women could describe pneumonia using closest word 'severe cold'. (29) More than $80 \%$ mothers in Peru know that chest in-drawing and rapid breathing are signs of pneumonia. (29) Commonest symptom reported by mothers were cough (40\%), with worsening in winter (87\%); dust was blamed as an aggravating factor (81\%); complications of pneumonia were correctly reported by $83 \%$. (24) About $30 \%$ mother had understanding of signs and symptoms before child was admitted; which included, chest retractions, difficulty in breathing, noisy breathing, and the child refusing breast milk or crying a lot. (30) Commonest danger signal mentioned was severe weakness (65.11\%) and least mentioned (5.04\%) was unconsciousness. (23) About 50\% identified correctly fast/difficult breathing as suggestive of pneumonia. (31) Contrarily fast breathing/difficult breathing and chest in-drawing are not much known. $(17,22-23)$ Recognition of fast breathing/difficult breathing was up-to $86.5 \%$. $(25,33)$ Inability to breast feed/ refusing to breast feeding were recognized as danger signals. (22) Fast breathing, difficulty in breathing, chest wall in-drawing and stridor were recognized as danger signs in that order and 34\% mothers did not even know one danger sign; they perceived fever, fast breathing and continuous cough as danger signs. (36) In current study danger signs of pneumonia were correctly told by $33 \%$ of women. The awareness about danger signs in ARI in Maharashtra increased from 29.2 to $52.2 \%$ in five years. (52) Globally about $20 \%$ mothers know danger signs of pneumonia. (10) Most felt that high fever, cold and chest in-drawing necessitates doctor's consultation. (17) Like present study in Karachi also more than $75 \%$ mothers were aware that usual ARI may also turn fatal. (24) If danger signs are recognized, mothers urgently seek care. (33) Attitudes toward treatment seeking were positive. (54).

\section{Conclusion}

After conducting three rounds of BCC activities using different media, knowledge related to risk factors and pneumonia improved significantly and retained till one year. Highest improvement was observed in hand washing skills. Serial use of different media at appropriate interval spread over a long period may yield desired results at diverse places.

\section{Recommendation}

Various medias may be used for behavioral change communication. Only small groups may be considered for conducting sessions. For skill acquisition practicing is an important aspect. There should be appropriate interval between two consecutive exposures. ASHAs may be trained to conduct such sessions.

\section{Limitation of the study}

Control group and non-slum urban areas were not included. Stop clock to measure the time taken for hand washing was not used.

\section{Relevance of the study}

Pneumonia is the leading cause of mortality among children one to six years. Mothers' knowledge and perceptions can identify risk factors and modify the health seeking behavior. Universalization of such behavioral change communication activities will reduce morbidity and mortality due to childhood pneumonia. The model we have suggested is not having high resources demand.

\section{Authors Contribution}

DPP, GJS, DGB, PPD and LSK initiated the concept of the project. DPP, GJS, PPD finalized the tools and conducted initial trainings. QSR, MSK, PRS, WVB, DRV and PSH conducted trainings and supervised the trainings. QSR, MSK, PRS, WVB, DRV and PSH supervised data collection. DPP and GJS prepared draft manuscript including data analysis and literature search. All authors have read and approved the manuscript.

\section{Acknowledgement}

We thank all the concerned officials and Dr. Manoj Das from INCLEN Trust International for their support.

\section{References}

1. Abass N, Abd El Aziz M, Hal N, Tawfeek R, Gamal R, Koraiem M, Magdy R, Zahran H, Hamza R. Effect of structured patient education program on the knowledge level of mothers regarding childhood gastroenteritis and pneumonia at El-Raml Pediatric Hospital. Current Pediatric Research. 2017 Jul 1;21(3):368-74.

2. World Health Organization. Available from: http://www.who.int/maternal_child_adolescent/news_events/ne ws/2011/pneumonia/en/. [Accessed on 08/06/19].

3. World Health Organization, \& UNICEF. Global action plan for prevention and control of pneumonia (GAPP). 2009.

4. Office of the Registrar General, Ministry of Home Affairs, Government of India. Report on Medical Certification of Cause of Death. New Delhi. 2015. 
5. Mathew JL. Pneumococcal vaccination in developing countries: Where does science end and commerce begin?. Vaccine. $2009 \mathrm{Jul}$ 9;27(32):4247-51.

6. Million Death Study Collaborators. Causes of neonatal and child mortality in India: a nationally representative mortality survey. The Lancet. 2010 Nov 27;376 (9755):1853-60.

7. Walker, C. L. F., Rudan, I., Liu, L., Nair, H., Theodoratou, E., Bhutta, Z. A., ... \& Black, R. E. Global burden of childhood pneumonia and diarrhoea. The Lancet, 2013; 381(9875): 1405-1416.

8. Izadnegahdar R, Cohen AL, Klugman KP, Qazi SA. Childhood pneumonia in developing countries. The Lancet Respiratory Medicine 2013 Sep 1;1(7):574-84.

9. Rudan I, Boschi-Pinto C, Biloglav Z, Mulholland K, Campbell H. Epidemiology and etiology of childhood pneumonia. Bulletin of the world health organization. 2008;86:408-16B.

10. Wardlaw TM, Johansson EW, Hodge MJ. Pneumonia: the forgotten killer of children. The United Nations Children's Fund (UNICEF). World health organization (WHO); 2006: 4337-9.

11. Farooqui $\mathrm{H}$, Jit M, Heymann DL, Zodpey S. Burden of severe pneumonia, pneumococcal pneumonia and pneumonia deaths in Indian states: modelling based estimates. PloS one. 2015 Jun 18;10(6):e0129191.

12. Ghimire M, Bhattacharya SK, Narain JP. Pneumonia in South-East Asia region: public health perspective. The Indian journal of medical research. 2012 Apr;135(4):459-68.

13. Mathew JL, Patwari AK, Gupta $P$, Shah D, Gera T, Gogia S, Mohan $P$, Panda $\mathrm{R}$, Menon S. Acute respiratory infection and pneumonia in India: a systematic review of literature for advocacy and action: UNICEF-PHFI series on newborn and child health, India. Indian pediatrics 2011 Mar 1;48(3):191-218.

14. International Institute for Population Sciences, Ministry of Health and Family Welfare, Government of India. National Family Health Survey-4, 205-16; Maharashtra Fact Sheet. 2017.

15. Rudan I, O’brien KL, Nair H, Liu L, Theodoratou E, Qazi S, Lukšić I, Walker CL, Black RE, Campbell H, Child Health Epidemiology Reference Group. Epidemiology and etiology of childhood pneumonia in 2010: estimates of incidence, severe morbidity, mortality, underlying risk factors and causative pathogens for 192 countries. Journal of global health 2013 Jun;3(1):1-14.

16. Datta SS, Singh Z, Boratne AV, Senthilvel V, Bazroy J, Dimri D. Knowledge and practice of handwashing among mothers of under five children in rural coastal South India. International Journal of Medicine and Public Health 2011;1(1):33-8.

17. Awasthi S, Nichter M, Verma T, Srivastava NM, Agarwal M, Singh $\mathrm{JV}$, Team CL. Revisiting community case management of childhood pneumonia: perceptions of caregivers and grass root health providers in Uttar Pradesh and Bihar, Northern India. PloS one 2015 Apr 21;10(4):e0123135.

18. World Health Organization \& UNICEF. Ending preventable child deaths from pneumonia and diarrhoea by 2025: The integrated Global Action Plan for Pneumonia and Diarrhoea (GAPPD).2013.

19. UNICEF. Global Hand Washing day. 2018. Available from: https://www.unicef.org.hk/en/event/global-handwashingday/clean-hands-save-lives/. [Accessed on 08/06/19].

20. National Health Mission, Ministry of Health \& Family Welfare, Government of India. ASHA Training Modules. 2005. Available from:

http://www.nhm.gov.in/communitisation/asha/resources/ashatraining-modules.html. [Last accessed on 2019 June 8].

21. World Health Organization, Department of Maternal NC and $\mathrm{AH}$, World Health Organization. Revised WHO classification and treatment of pneumonia in children at health facilities: evidence summaries. (Internet). $2014 . \quad$ Available at: http://www.ncbi.nlm.nih.gov/books/NBK264162/. (Accessed on 08/06/19).

22. Muro F, Meta J, Renju J, Mushi A, Mbakilwa H, Olomi R, Reyburn H, Hildenwall $\mathrm{H}$. "It is good to take her early to the doctor"-mothers' understanding of childhood pneumonia symptoms and health care seeking in Kilimanjaro region, Tanzania. BMC international health
[Model package of...] | Prabhakarrao DP et al and human rights, 2017 Dec; 17(1), 27. DOI 10.1186/s12914-0170135-1.

23. Tuhebwe D, Tumushabe E, Leontsini E, Wanyenze RK. Pneumonia among children under five in Uganda: symptom recognition and actions taken by caretakers. African Health Sciences 2014;14(4):993-1000.

24. Bham SQ, Saeed F, Shah MA. Knowledge, Attitude and Practice of mothers on acute respiratory infection in children under five years. Pakistan Journal of Medical Sciences 2016;32(6):1557-1561.

25. Minz A, Agarwal M, Singh JV, Singh VK. Care seeking for childhood pneumonia by rural and poor urban communities in Lucknow: A community-based cross-sectional study. Journal of family medicine and primary care $2017 \mathrm{Apr} ; 6(2): 211-217$.

26. Khan S, Kumar V, Priya N, Yadav SS. Handwashing practices among the caregivers of under five children in rural and urban areas of Moradabad, India: a community based study. Int J Med Sci Public Health 2017;6(1):133-8.

27. Siswanto E, Bhuiyan SU, Chompikul J. Knowledge and perception of pneumonai disease among mothers of children under five years attending Nakhon Pathom General Hospital, Thailand. Journal of Public Health and Development 2007; 5 (2):43-54.

28. Pradhan SM, Rao AP, Pattanshetty SM, Nilima AR. Knowledge and perception regarding childhood pneumonia among mothers of under-five children in rural areas of Udupi Taluk, Karnataka: A cross-sectional study. Indian Journal of Health Sciences and Biomedical Research (KLEU) 2016 Jan 1;9)1):35-39.

29. Galvez CA, Modeste N, Lee JW, Betancourt H, Wilkins RL. Peruvian mothers' knowledge and recognition of pneumonia in children under 5 years of age. Revista Panamericana de Salud Pública 2002;11:99-108.

30. Ferdous F, Dil Farzana F, Ahmed S, Das SK, Malek MA, Das J, Faruque AS, Chisti MJ. Mothers' perception and healthcare seeking behavior of pneumonia children in rural Bangladesh. ISRN family medicine 2014 Feb 23;2014.

31. Abolwafa NF, Mohamed AH. Effect of Educational Program on Mothers Knowledge about Prevention of Pneumonia for their Children under Five Years. IOSR Journal of Nursing and Health Science (IOSR-JNHS) 2017; 6 (5): 05-12.

32. Ekure EN, Esezobor $\mathrm{Cl}$, Balogun MR, Mukhtar-Yola M, Ojo OO, Emodi IJ, Omoigberale AI, Oviawe O, Ezechukwu CC, Olowu AO, Ogala WN. Mothers and childhood pneumonia: what should the focus of public campaigns be? Nigerian Journal of Paediatrics 2013;40(1):24-9.

33. Mull DS, Mull JD, Kundi MM, Anjum M. Mothers' perceptions of severe pneumonia in their own children: a controlled study in Pakistan. Social science \& medicine 1994 Apr 1;38(7):973-87.

34. Parvez MM, Wiroonpanich W, Naphapunsakul M. The effects of educational program on child care knowledge and behaviors of mothers of children under five years with pneumonia. Bangladesh Journal of Medical Science 2010 Jul 1;9(3):136-42.

35. Fonseca W, Kirkwood BR, Victora CG, Fuchs SR, Flores JA, Misago C. Risk factors for childhood pneumonia among the urban poor in Fortaleza, Brazil: a case--control study. Bulletin of the World Health Organization 1996;74(2):199-208.

36. Ndu IK, Ekwochi U, Osuorah CD, Onah KS, Obuoha E, Odetunde OI, Nwokoye I, Obumneme-Anyim NI, Okeke IB, Amadi OF. Danger signs of childhood pneumonia: caregiver awareness and care seeking behavior in a developing country. International journal of pediatrics 2015;1-7.

37. Awasthi S, Verma T, Agarwal M, Singh JV, Srivastava NM, Nichter M. Developing effective health communication messages for community acquired pneumonia in children under five years of age: A rural North Indian qualitative study. Clinical Epidemiology and Global Health 2017 Sep 1;5(3):107-16.

38. Dherani M, Pope D, Mascarenhas M, Smith KR, Weber M, Bruce N. Indoor air pollution from unprocessed solid fuel use and pneumonia risk in children aged under five years: a systematic review and meta-analysis. Bulletin of the World Health Organization 2008;86:390-98. 
39. Karki S, Fitzpatrick AL, Shrestha S. Risk factors for Pneumonia in Children under 5 years in a Teaching Hospital in Nepal. Kathmandu Univ Med J 2014 Oct 1;12:247-52.

40. Vujcic J, Ram PK. Handwashing Promotion: Monitoring and Evaluation Module. United Nations Children's Fund, New York, NY. 2013.

41. UNICEF. Fast Facts And Figures About Hand washing. Available from: http://unicef.in/Story/129/Fast-Facts-And-Figures-AboutHand. [Last accessed on 2019 June 8].

42. Rabie $T$, Curtis V. Handwashing and risk of respiratory infections: a quantitative systematic review. Tropical medicine \& international health 2006 Mar;11(3):258-67.

43. Luby SP, Agboatwalla M, Feikin DR, Painter J, Billhimer W, Altaf A, Hoekstra RM. Effect of handwashing on child health: a randomised controlled trial. The Lancet $2005 \mathrm{Jul}$ 16;366 (9481):225-33.

44. Jefferson T, Foxlee R, Del Mar C, Dooley L, Ferroni E, Hewak B, Prabhala A, Nair S, Rivetti A. Physical interventions to interrupt or reduce the spread of respiratory viruses: systematic review. BMJ 2008 Jan 10;336(7635):77-80.

45. Kamm KB, Feikin DR, Bigogo GM, Aol G, Audi A, Cohen AL, Shah MM, Yu J, Breiman RF, Ram PK. Associations between presence of handwashing stations and soap in the home and diarrhoea and respiratory illness, in children less than five years old in rural western Kenya. Tropical Medicine \& International Health 2014 Apr;19(4):398-406.

46. Ram P. Practical guidance for measuring handwashing behavior. Water and Sanitation Program. 2010.

47. Ray SK, Zaman FA, Laskar NB. Hand washing practices in two communities of two states of Eastern India: an intervention study. Indian Journal of Public Health 2010 Jul 1;54(3):126-130.

48. Dhakal S, Lee TH, Nam EW. Exclusive Breastfeeding Practice and Its Association among Mothers of under 5 Children in Kwango District, DR Congo International Journal of Environmental Research and Public Health 2017;14(5):455. doi:10.3390/ijerph14050455.
49 breast feeding practices of postnatal mothers: A cross sectional survey. International journal of health sciences 2015 Oct;9(4):364374.

50. Thomas S, Poornima S, Vinay M. Knowledge, Attitudes, and Practices of Mothers Regarding Breastfeeding: A Cross Sectional Study In Selected Rural Area of Mandya District, Karnataka. National Journal of Research in Community Medicine 2017; 6(2):151-57.

51. Singh J, Bhardwar V, Kumra A. Knowledge, attitude and practice towards exclusive breastfeeding among lactating mothers: descriptive cross sectional study. International Journal of Medical and Dental Sciences 2018 Jan 9;7(1):1586-93.

52. International Institute for Population Sciences, Ministry of Health and Family Welfare, Government of India. District Level Household and Facility Survey -4: State Fact Sheet Maharashtra. (2012-13).

53. Mckay CC, Chang AB, Versteegh LA, McCallum GB. Culturally appropriate flipcharts improve the knowledge of common respiratory conditions among Northern Territory Indigenous families. Health Promotion Journal of Australia 2015 Aug;26(2):150-3.

54. Alluqmani MF, Abdullah Aloufi A, Abdulwahab A, Makki A, AIShathri AA, AIShehri MS, Hawsawi SI, Alshmmary NA, Alshammari BJ. Knowledge, Attitude and Practice of Mothers on Acute Respiratory Infection in Children under Five Years in Saudi Arabia, 2017. Egyptian Journal of Hospital Medicine 2017 Oct 3;69(2):1959-1963.

55. Farhad J, Malihe A, Azami Fatemeh A, Mahmood S. The Knowledge, Attitude and Practice of Mothers Regarding Acute Respiratory Tract Infection in Children. Biosci Biotech Res Asia 2014 Apr;11(1):343-8

56. Van Ginneken JK, Lob-Levyt J, Gove S. Potential interventions for preventing pneumonia among young children in developing countries: promoting maternal education. Tropical Medicine \& International Health 1996 Jun;1(3):283-94.

\section{Tables}

\section{TABLE 1 TEST WISE MARKS OBTAINED BY MOTHERS ( $N=1321$ )}

\begin{tabular}{|c|c|c|c|c|c|c|c|c|c|}
\hline \multirow{2}{*}{$\begin{array}{l}\text { Q. } \\
\text { No. }\end{array}$} & \multirow[t]{2}{*}{ Questions } & \multirow[t]{2}{*}{ D } & \multirow[t]{2}{*}{$M$} & \multicolumn{2}{|c|}{ Pre-test } & \multicolumn{2}{|c|}{ Post-test 3} & \multicolumn{2}{|c|}{ Significance } \\
\hline & & & & Mean & S.D. & Mean & S.D. & $\mathrm{t}$ & $\mathrm{p}$ \\
\hline 1 & $\begin{array}{l}\text { When should mother breast } \\
\text { feed baby after birth? }\end{array}$ & K & 1 & 0.79 & 0.41 & 0.96 & 0.19 & 14.17 & $<0.01$ \\
\hline 2 & $\begin{array}{l}\text { How to know that the breast } \\
\text { milk is sufficient to baby? }\end{array}$ & K & 1 & 0.28 & 0.45 & 0.73 & 0.44 & 79.69 & $<0.01$ \\
\hline 3 & $\begin{array}{l}\text { What is duration of } \\
\text { exclusive breast feeding? }\end{array}$ & K & 1 & 0.63 & 0.48 & 0.89 & 0.31 & 17.81 & $<0.01$ \\
\hline 4 & $\begin{array}{l}\text { What is the reason of } \\
\text { malnutrition in child? }\end{array}$ & K & 1 & 0.80 & 0.40 & 0.94 & 0.23 & 11.60 & $<0.01$ \\
\hline 5 & $\begin{array}{l}\text { In which month first dose } \\
\text { of Vitamin } A \text { is given? }\end{array}$ & K & 1 & 0.28 & 0.45 & 0.88 & 0.32 & 41.19 & $<0.01$ \\
\hline 6 & $\begin{array}{l}\text { Which is best type of } \\
\text { fuel for cooking? }\end{array}$ & K & 1 & 0.85 & 0.35 & 0.99 & 0.11 & 13.52 & $<0.01$ \\
\hline 7 & $\begin{array}{l}\text { Indoor air pollution leads } \\
\text { to which type of diseases? }\end{array}$ & K & 1 & 0.85 & 0.36 & 0.97 & 0.18 & 10.92 & $<0.01$ \\
\hline 8 & $\begin{array}{l}\text { What is the danger } \\
\text { sign of pneumonia? }\end{array}$ & K & 1 & 0.33 & 0.47 & 0.95 & 0.21 & 45.14 & $<0.01$ \\
\hline 9 & $\begin{array}{l}\text { Which children are at high } \\
\text { risk for getting pneumonia? }\end{array}$ & K & 1 & 0.68 & 0.47 & 0.93 & 0.26 & 16.65 & $<0.01$ \\
\hline 10 & $\begin{array}{l}\text { What are the moments } \\
\text { need hand washing? }\end{array}$ & K & 4 & 2.72 & 1.26 & 3.48 & 0.84 & 18.97 & $<0.01$ \\
\hline 11 & Malnutrition & $\mathrm{P}$ & 5 & 3.33 & 0.80 & 4.52 & 0.68 & 39.86 & $<0.01$ \\
\hline 12 & $\begin{array}{l}\text { Indoor pollution } \\
\text { and pneumonia }\end{array}$ & $P$ & 6 & 4.84 & 0.89 & 5.80 & 0.58 & 45.98 & $<0.01$ \\
\hline 13 & Pneumonia & $\mathrm{P}$ & 5 & 3.67 & 0.77 & 4.61 & 0.64 & 34.14 & $<0.01$ \\
\hline 14 & Steps of hand washing & $\mathrm{S}$ & 9 & 2.62 & 1.94 & 8.57 & 1.11 & 94.37 & $<0.01$ \\
\hline
\end{tabular}




\section{TABLE 2 AREA WISE KNOWLEDGE AND PERCEPTION OF MOTHERS AND CHANGE AFTER BCC}

\begin{tabular}{|c|c|c|c|c|c|c|}
\hline \multirow[t]{3}{*}{ Aspects (Domain) } & \multicolumn{3}{|l|}{ Pre-test } & \multicolumn{3}{|l|}{ Post-test 3} \\
\hline & Urban $n=817$ & Rural $n=504$ & \multirow[t]{2}{*}{$\mathrm{p}$} & Urban $n=817$ & Rural $n=504$ & \multirow[t]{2}{*}{$\mathrm{p}$} \\
\hline & Mean marks & Mean marks & & Mean increase & Mean increase & \\
\hline Breast feeding (K) & 1.64 & 1.80 & $<0.01$ & 1.01 & 0.71 & $<0.01$ \\
\hline Indoor air pollution (K) & 1.75 & 1.63 & $<0.01$ & 0.22 & 0.32 & $<0.01$ \\
\hline Malnutrition (K) & 1.07 & 1.08 & 0.82 & 0.80 & 0.68 & $<0.01$ \\
\hline Pneumonia (K) & 1.01 & 1.01 & 0.94 & 0.90 & 0.83 & 0.12 \\
\hline Moments needing hand washing (K) & 2.69 & 2.77 & 0.27 & 0.80 & 0.71 & 0.30 \\
\hline Indoor air pollution (P) & 2.23 & 2.26 & 0.26 & 0.69 & 0.61 & 0.01 \\
\hline Malnutrition $(P)$ & 3.36 & 3.28 & 0.07 & 1.09 & 1.37 & $<0.01$ \\
\hline Pneumonia (P) & 5.94 & 5.88 & 0.29 & 1.79 & 1.28 & $<0.01$ \\
\hline Steps of hand washing (S) & 2.44 & 2.91 & $<0.01$ & 6.12 & 5.68 & $<0.01$ \\
\hline Total score & 22.12 & 22.60 & 0.03 & 13.39 & 12.18 & $<0.01$ \\
\hline
\end{tabular}

\section{TABLE 3 KNOWLEDGE AND PERCEPTION OF MOTHERS AND CHANGE BY AGE GROUPS AFTER BCC ACTIVITIES}

\begin{tabular}{|c|c|c|c|c|c|c|}
\hline \multirow[t]{3}{*}{ Aspects (Domain) } & \multicolumn{3}{|c|}{ Pre-test marks } & \multicolumn{3}{|c|}{ Changed marks after BCC } \\
\hline & $\begin{array}{l}\text { Age } \leq 25 \\
(n=792)\end{array}$ & $\begin{array}{l}\text { Age }>25 \\
(n=529)\end{array}$ & \multirow[t]{2}{*}{$p$} & $\begin{array}{l}\text { Age } \leq 25 \\
(n=792)\end{array}$ & $\begin{array}{l}\text { Age }>25 \\
(n=529)\end{array}$ & \multirow[t]{2}{*}{$p$} \\
\hline & Mean & Mean & & Mean increase & Mean increase & \\
\hline Breast feeding (knowledge) & 1.68 & 1.72 & 0.35 & 0.86 & 0.95 & 0.13 \\
\hline Indoor air pollution (knowledge) & 1.69 & 1.72 & 0.31 & 0.25 & 0.25 & 0.99 \\
\hline Malnutrition (knowledge) & 1.05 & 1.11 & 0.12 & 0.75 & 0.75 & 0.85 \\
\hline Pneumonia (knowledge) & 0.99 & 1.04 & 0.28 & 0.88 & 0.86 & 0.66 \\
\hline Moments needing hand washing (knowledge) & 2.71 & 2.73 & 0.76 & 0.77 & 0.75 & 0.74 \\
\hline Indoor air pollution (perception) & 2.22 & 2.28 & 0.02 & 0.68 & 0.63 & 0.13 \\
\hline Malnutrition (perception) & 3.33 & 3.33 & 0.99 & 1.18 & 1.22 & 0.45 \\
\hline Pneumonia (perception) & 5.89 & 5.95 & 0.25 & 1.56 & 1.66 & 0.20 \\
\hline Steps of hand washing (Skills) & 2.70 & 2.49 & 0.06 & 5.82 & 6.15 & 0.01 \\
\hline Total score & 22.26 & 22.36 & 0.65 & 12.74 & 13.22 & 0.08 \\
\hline
\end{tabular}

TABLE 4 KNOWLEDGE \& PERCEPTION OF MOTHERS AND EDUCATIONAL LEVEL BEFORE BCC ACTIVITIES

\begin{tabular}{|c|c|c|c|c|c|c|c|c|c|c|c|c|}
\hline \multirow[t]{2}{*}{ Aspects (Domain) } & \multicolumn{2}{|c|}{$\begin{array}{l}\text { No formal } \\
\text { education } \\
(n=55)\end{array}$} & \multicolumn{2}{|c|}{$\begin{array}{l}\text { Up to SSC* } \\
(n=461)\end{array}$} & \multicolumn{2}{|c|}{$\begin{array}{l}\text { SSC } \\
(n=401)\end{array}$} & \multirow{2}{*}{$\begin{array}{l}\text { HSC**/ } \\
(n=253)\end{array}$} & \multirow{2}{*}{$\begin{array}{l}\text { Diploma } \\
\text { SD }\end{array}$} & \multicolumn{2}{|c|}{$\begin{array}{l}\text { Graduate and } \\
\text { above }(n=141)\end{array}$} & \multirow[t]{2}{*}{$\mathrm{F}$} & \multirow[t]{2}{*}{$\mathrm{P}$} \\
\hline & Mean & SD & Mean & SD & Mean & SD & & & Mean & SD & & \\
\hline Breast feeding (knowledge) & 1.62 & 0.95 & 1.48 & 0.87 & 1.71 & 0.82 & 1.91 & 0.81 & 2.00 & 0.89 & 15.99 & $<0.01$ \\
\hline $\begin{array}{l}\text { Indoor air pollution } \\
\text { (knowledge) }\end{array}$ & 1.45 & 0.69 & 1.60 & 0.62 & 1.72 & 0.52 & 1.83 & 0.41 & 1.88 & 0.37 & 15.73 & $<0.01$ \\
\hline Malnutrition (knowledge) & 0.82 & 0.75 & 0.95 & 0.70 & 1.10 & 0.58 & 1.24 & 0.53 & 1.24 & 0.56 & 14.39 & $<0.01$ \\
\hline Pneumonia (knowledge) & 0.78 & 0.62 & 0.93 & 0.72 & 1.00 & 0.69 & 1.17 & 0.70 & 1.14 & 0.71 & 7.93 & $<0.01$ \\
\hline $\begin{array}{l}\text { Moments needing hand } \\
\text { washing (knowledge) }\end{array}$ & 2.69 & 1.14 & 2.51 & 1.32 & 2.63 & 1.26 & 2.96 & 1.21 & 3.21 & 1.01 & 11.38 & $<0.01$ \\
\hline $\begin{array}{l}\text { Indoor air pollution } \\
\text { (perception) }\end{array}$ & 2.31 & 0.40 & 2.21 & 0.48 & 2.24 & 0.46 & 2.28 & 0.41 & 2.26 & 0.39 & 1.26 & 0.28 \\
\hline Malnutrition (perception) & 3.43 & 0.87 & 3.46 & 0.93 & 3.32 & 0.76 & 3.18 & 0.65 & 3.14 & 0.57 & 7.66 & $<0.01$ \\
\hline Pneumonia (perception) & 6.15 & 0.80 & 5.87 & 1.14 & 5.95 & 0.96 & 5.92 & 0.94 & 5.81 & 0.98 & 1.61 & 0.17 \\
\hline Steps of hand washing -skills & 2.00 & 1.12 & 2.38 & 1.75 & 2.65 & 2.03 & 3.02 & 2.19 & 2.87 & 1.95 & 6.72 & $<0.01$ \\
\hline Total score & 21.25 & 2.92 & 21.40 & 3.97 & 22.32 & 3.96 & 23.51 & 3.89 & 23.55 & 3.59 & 17.25 & $<0.01$ \\
\hline
\end{tabular}

TABLE 5 INCREASE IN KNOWLEDGE \& PERCEPTION OF MOTHERS AND EDUCATIONAL LEVEL AFTER BCC ACTIVITIES

\begin{tabular}{|c|c|c|c|c|c|c|c|c|c|c|c|c|}
\hline \multirow[t]{2}{*}{ Aspects (Domain) } & \multicolumn{2}{|c|}{$\begin{array}{l}\text { No formal } \\
\text { education } n=55\end{array}$} & \multicolumn{2}{|c|}{$\begin{array}{l}\text { Up to SSC * } \\
(n=461)\end{array}$} & \multicolumn{2}{|c|}{$\begin{array}{l}\text { SSC } \\
(n=401)\end{array}$} & \multicolumn{2}{|c|}{$\begin{array}{l}\text { HSC**/ Diploma } \\
(n=253)\end{array}$} & \multicolumn{2}{|c|}{$\begin{array}{l}\text { Graduate and } \\
\text { above }(n=141)\end{array}$} & \multirow[t]{2}{*}{$\mathrm{F}$} & \multirow[t]{2}{*}{$P$} \\
\hline & Mean & SD & Mean & SD & Mean & SD & Mean & SD & Mean & SD & & \\
\hline Breast feeding (knowledge) & 0.85 & 1.27 & 1.02 & 1.10 & 0.89 & 0.95 & 0.77 & 0.96 & 0.74 & 1.00 & 3.35 & $<0.01$ \\
\hline $\begin{array}{l}\text { Indoor air pollution } \\
\text { (knowledge) }\end{array}$ & 0.49 & 0.73 & 0.34 & 0.67 & 0.25 & 0.55 & 0.15 & 0.44 & 0.09 & 0.41 & 10.49 & $<0.01$ \\
\hline Malnutrition (knowledge) & 0.92 & 0.92 & 0.86 & 0.85 & 0.74 & 0.68 & 0.63 & 0.60 & 0.56 & 0.68 & 7.4 & $<0.01$ \\
\hline Pneumonia (knowledge) & 1.02 & 0.76 & 0.91 & 0.84 & 0.89 & 0.76 & 0.77 & 0.74 & 0.80 & 0.74 & 2.17 & 0.07 \\
\hline $\begin{array}{l}\text { Moments needing hand } \\
\text { washing (knowledge) }\end{array}$ & 0.62 & 1.50 & 1.00 & 1.53 & 0.78 & 1.48 & 0.52 & 1.46 & 0.43 & 1.00 & 6.99 & $<0.01$ \\
\hline $\begin{array}{l}\text { Indoor air pollution } \\
\text { (perception) }\end{array}$ & 0.58 & 0.47 & 0.67 & 0.55 & 0.69 & 0.51 & 0.64 & 0.47 & 0.62 & 0.57 & 0.89 & 0.47 \\
\hline Malnutrition (perception) & 1.02 & 1.05 & 0.98 & 1.23 & 1.25 & 1.02 & 1.41 & 0.93 & 1.44 & 0.93 & 9.57 & $<0.01$ \\
\hline Pneumonia (perception) & 1.38 & 0.93 & 1.61 & 1.38 & 1.57 & 1.18 & 1.65 & 1.23 & 1.67 & 1.47 & 0.73 & 0.57 \\
\hline Steps of hand washing (skills) & 6.54 & 1.51 & 6.13 & 2.08 & 5.89 & 2.39 & 5.66 & 2.54 & 5.77 & 2.40 & 3.13 & 0.01 \\
\hline Total score & 13.42 & 4.02 & 13.51 & 4.87 & 12.94 & 4.69 & 12.19 & 4.90 & 12.12 & 4.68 & 4.43 & $<0.01$ \\
\hline
\end{tabular}




\section{Figures}

FIGURE 1 STUDY AREA AND CLUSTERS SELECTED, MAHARASHTRA, 2015-17

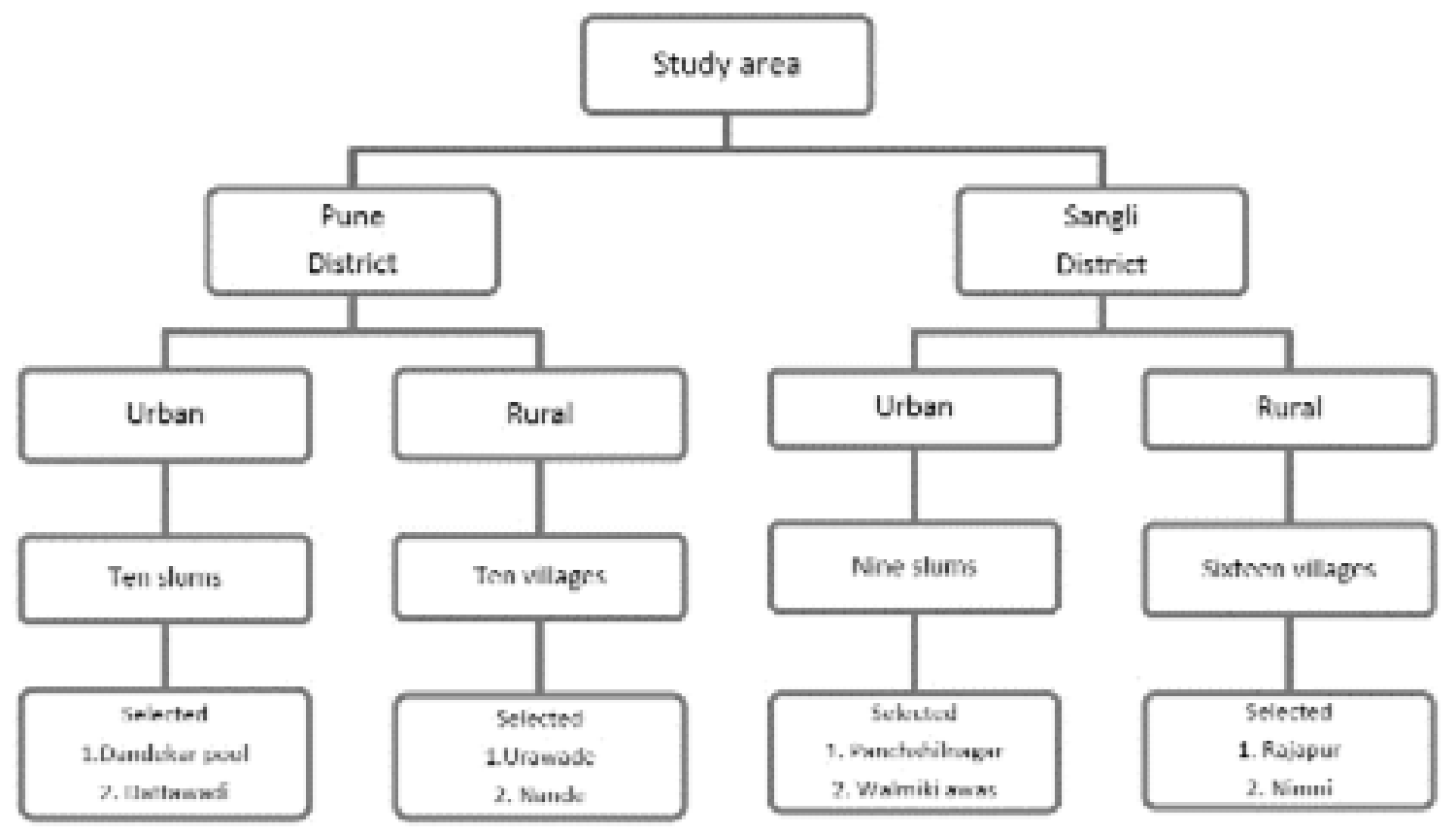

